\title{
Positive Terms-of-Trade Shocks and Structural Adjustment in Sub-Saharan Africa
}

\author{
Martin Brownbridge and Jane Harrigan*
}

Recent research has developed and tested a theoretical framework for analysing the macro and micro economic effects of temporary positive external trade shocks in small open developing economies (Bevan et al., 1990). The findings, termed 'construction boom theory', suggest that the extent to which a boom's transient windfall income is converted into a permanent income gain depends upon the savings responses of the public and private sectors and their ability to allocate savings among different fixed and financial assets. The nature of the economic policy regime plays a crucial role. An extensive system of controls over prices, interest rates, imports and foreign asset purchases is likely to induce a sub-optimal allocation of the windfall resources and to depress rates of return to saving and thus permanent income gains. Moreover, an inappropriate macroeconomic policy response during the boom (especially an excessive expansion of public spending, rapid growth of the money supply and an appreciation of the real exchange rate) may have very serious adverse consequences for external and internal macroeconomic imbalances during and/or following the end of the boom. Macroeconomic problems include excessively large construction booms, declining tradeables output, over-extended public sectors, unsustainable public deficits, overvalued exchange rates and inflation. Many of these problems ultimately contributed to the need for the structural adjustment programmes (SAPs) which have been under way in much of sub-Saharan Africa for well over a decade. The aim of this article is to assess these SAPs from the standpoint of whether the reforms have left adjusting countries in a better position to manage temporary positive external trade shocks or commodity price booms in three important respects: diversifying the economy; efficiently saving and investing boom income; and appropriately managing the macroeconomy in the face of a positive trade shock.

The construction boom literature is intended to be applicable to what are termed 'controlled open economies', the pertinent features of which are their openness to international trade, the extensiveness of government controls over private sector economic activity, and their reliance on a small number of

* Consultant, UNCTAD, Geneva, Switzerland and Lecturer, School of Economic Studies, University of Manchester, UK, respectively. 
primary commodities for foreign-exchange earnings. It is arguable that most SSA economies can be (or could have been) characterised in this manner.' Primary commodities accounted for $89 \%$ of the SSA region's total export earnings in 1990 (UNCTAD, 1993a: 99). Of the 28 SSA countries classified by UNCTAD as 'least developed countries', 18 relied on a single commodity for at least 50\% of their total export earnings (UNCTAD, 1993c: A-16 to A-19).

Most SSA countries are price takers on world markets for their primary commodity exports, and these prices display far greater short-term instability than do the prices for non-primary tradeable commodities (Kaldor, 1987; Maizels, 1987 and 1992). Short sharp peaks in commodity prices are interspersed between longer but shallower troughs, and these fluctuations influence the economies of the SSA exporters through a number of crucial channels. Export earnings are the major determinant of the availability of imported inputs and hence the economy's aggregate supply schedule. Aggregate demand is also likely to be sensitive to the prices received for commodity exports. Export earnings may influence a country's foreign creditworthiness. Finally, the government revenue base is generally heavily dependent upon taxes levied on exports and/or imports, so that the budget deficit is vulnerable to changes in the value of export earnings. ${ }^{2}$

\section{CBT and the macroeconomic effects of construction booms}

Construction boom theory (CBT) is an extension of the open economy macroeconomics known as Dutch Disease theory, which examines the impacts of permanent changes to the external trading opportunities facing an economy which directly increase permanent income (Corden, 1984; Neary, 1984; van Wijnbergen, 1984). In contrast, CBT deals with short-term changes to the external trading environment which tend to characterise primary commodity-producing economies and which increase transient rather than permanent income (such as the temporary commodity price boom in the second half of the 1970s). The transitory nature of these shocks has two important implications. First, CBT argues that the major effects of transitory income gains are normally higher levels of saving and investment. Secondly, whereas Dutch Disease theory is conducted mainly within the framework of comparative statics,

1. This description is not time-invariant, especially as most SSA countries which have implemented SAPs during the 1980s and early 1990s have made efforts to reduce and/or dismantle substantial elements of their control regimes in line with the market-liberalising strategy of these programmes.

2. Trade taxes contributed nearly $43 \%$ of total tax revenues in a sample of 25 SSA countries in 1982 (Shalizi and Squire, 1988: 3). 
the analysis of temporary commodity price booms involves consideration of the dynamic adjustment to a rise and then fall in transitory income.

Construction booms and Dutch Disease are also characterised by different expectational properties. A permanent Dutch Disease shock gives rise to exclusive revised expectations of permanent income; permanent income increases because of the expectation of higher income in the future which had not been expected prior to the shock. By contrast, the temporary positive terms-of-trade shock that leads to a construction boom is generally characterised by exclusive unrevised expectations; this is an unexpected shock which is recognised as temporary and thus does not lead agents to revise their expectations of future commodity prices. Permanent income does rise but only by an amount equivalent to the sustainable income flow which can be generated by investing the trade windfall, i.e. the long-run rate of return to saving. Given that the windfall is recognised as having only limited effects on permanent income, most of it will normally be saved.

During a construction boom investment will be influenced via two channels: the transient income or savings effect; and the permanent income or consumption effect. Under the former, windfall transient income is saved. This will cause a fall in the cost of investment funds and/or an increase in the quantity of credit available, so boosting investment. To the extent that the additional investment has a positive rate of return, permanent income will be perceived to increase which will induce a rise in consumption. This will force up both demand for and prices of non-tradeable consumption goods, as in Dutch Disease, with this relative price effect encouraging investment in the non-traded goods sector.

The increased investment brought about by both the transient and the permanent income effects of the positive terms-of-trade shock will increase the demand for capital goods. Tradeable capital goods will be imported, whilst excess demand for non-tradeable capital goods will force up their price and draw resources into this sector. Since it largely consists of construction activities, the upshot will be a construction boom. CBT therefore predicts an increase in the relative price of non-traded capital goods, with a sharp rise at the start of the boom followed by a gradual decline as the expansion of supply reduces excess demand.

During the boom, when the prices of non-tradeable capital goods are being forced up so reducing returns to investment, it makes sense to defer fixed investment and instead build up financial assets, which can be run down later to fund fixed investment when non-tradeable capital goods prices have subsided. ${ }^{3}$ This spreads the investment boom beyond the trade shock and will moderate the rise in the price of non-tradeable capital goods and therefore

3. This might be difficult to achieve if investors expect future capital goods prices to rise and so try to cram fixed investment into the immediate period. 
prevent the marginal efficiency of investment falling too rapidly. If private agents are deterred from acquiring financial savings, transient income will be either invested prematurely in fixed capital or possibly used to purchase consumption goods; in either case the rate of return to saving will fall and the permanent income gains from the trade boom will be reduced. A key issue is whether the government control regime permits the above rational response to a temporary positive terms-of-trade shock.

Government controls could prevent the accumulation of financial assets through two mechanisms. First, foreign-exchange controls may prevent the direct purchase of foreign assets by private agents. Second, nominal interest-rate controls and other restrictions on financial markets may depress the real rate of return available on domestic financial assets.

Import restrictions are also likely to distort the efficient allocation of boom income. Under a highly restrictive regime the increased demand for tradeable capital and consumer goods will drive up their prices (they will become effectively non-tradeable at the margin). Unless there is substantial excess capacity and unemployment, the only way in which increased demand can be accommodated is by a transfer of resources from the export sector. Non-boom exports will experience adverse relative price movements during a boom and it is possible that even the boom export sector will suffer from a fall in the internal terms of trade. The improvement in the current account brought about by the transient foreign-exchange earnings should therefore allow import restrictions to be liberalised to some extent during a trade boom.

Given that the optimal response to a trade boom involves an expansion followed by a contraction of the non-traded capital goods sector, accompanied by offsetting movements in other sectors of the economy, policies which discourage factor and resource mobility are likely to be an impediment to the efficient use of boom income. Such policies could include: controls on the import of construction materials or public sector monopolies on their production or supply; sectoral credit and foreign-exchange allocations; industrial and investment licensing; restrictions on foreign direct investment; and wage and price controls.

The trade boom will affect the exchange rate, the money supply and inflation. The supply of foreign exchange to the economy will rise during the boom. Agents will exchange this for domestic currency which is used to purchase capital and consumer goods. Under a fixed exchange-rate regime there will be, ceteris paribus, a balance-of-payments surplus and a rise in the money supply. The latter will lead to higher rates of domestic inflation, unless sterilised by the Central Bank, and to an appreciation of the real exchange rate. ${ }^{4}$ Under a flexible

4. These outcomes will be greater if institutional controls restrict imports and foreign asset accumulation, and if the public sector expands its external borrowing. 
exchange-rate regime the foreign currency windfall will induce a rise in both nominal and real exchange rates, but not necessarily in the money supply.

The positive terms-of-trade shock is likely to influence government revenues and expenditures. The boom will give rise to a temporary increase in revenues through growth of the revenue base, with substantial effects if revenue is heavily reliant upon trade taxes and if the foreign-exchange inflow facilitates a large rise in imports. Discretionary tax increases may also be levied on incomes or on the exports from the booming tradeables sector. Because of political and social pressures, revenue increases are likely to lead to an expansion of public expenditure. The commodity boom of the 1970s provided the opportunity for substantial increases in public expenditure in all but a few SSA countries (Bevan et al., 1990; Wetzel, 1992; Bevan et al., 1992; Harrigan, 1991; Little et al., 1993; Alpine and Pickett 1993). ${ }^{5}$ Enhanced access to external capital markets or to domestic finance in the form of private savings accrued out of transient incomes may provide governments with further opportunities to finance higher levels of expenditure. Concentrating the growth in public sector investment into the construction boom years will further raise the price of non-traded capital goods, causing inflation and reducing the marginal efficiency of investment and the increase in permanent income derived from the transient income windfall.

The increases in government revenues will probably not be sustainable once the boom has subsided. Government expenditures, for example on wages and subsidies, may prove politically much more difficult to reduce. It may not be possible to cut some categories of public expenditure such as debt servicing, and finance may have to be found for projects started during the boom. Unless the government can exercise considerable financial restraint it is therefore likely that the post-boom fiscal deficit will be larger than that prevailing before the boom.

Inflationary pressure will also arise from expenditure changes because of increased demand for non-traded goods, in particular non-traded capital goods. Inflation will be exacerbated to the extent that private savers are prevented from holding financial assets (in lieu of purchasing domestic fixed assets), if expansionary fiscal policies are pursued and if restrictive trade policies limit the extent to which the increased demand can be channelled into higher levels of imports.

Another legacy of the boom is likely to be a balance-of-payments deficit, which will arise for several reasons. First, the boom may induce unsustainable increases in aggregate demand, particularly if public expenditure expands. The external counterpart of excess demand in the traded goods sector will be a trade deficit. Secondly, domestic inflation during and after the boom and/or nominal

5. Public expenditure in SSA increased from $19 \%$ of GDP in 1970 to $29 \%$ in 1980 , with civil service employment and state enterprise investment in particular benefitting from the higher expenditures (Nashashibi and Bazzoni, 1993: 78). 
exchange-rate appreciation will induce an appreciation in the real exchange rate, which will damage the competitiveness of the non-booming traded goods sector and increase import demand. Thirdly, external debt-servicing requirements may increase as a result of foreign debt contracted during the boom. Fourthly, changes in the production structure during the boom may increase the import intensity of the economy. This might arise because real exchange-rate appreciation induces a reallocation of investment towards sectors which are more import-intensive, such as protected import-substituting industry, at the expense of labour- and natural resource-intensive sectors such as agriculture.

Analysis of commodity price booms affecting SSA countries in the 1970s, for example Kenya and Tanzania (Bevan et al., 1990); Ghana (Wetzel, 1992); Nigeria (Bevan et al., 1992); Malawi (Harrigan, 1991); Cameroon (Little et al., 1993) and Côte d'Ivoire (Alpine and Pickett, 1993) indicates that in most cases the appropriate policy reforms for managing the booms were not implemented. Fixed investment, including public sector investment, was excessively concentrated in the construction boom period, public expenditure rose rapidly, and governments undertook increased external borrowing. The efficiency of much of this public sector investment was low. Government controls in many countries inhibited deferral of private sector investment through financial asset accumulation and prevented factor mobility in response to the construction boom. Most countries also encountered severe balance-of-payments deficits once the boom had ended, with inflation and exchange-rate appreciation eroding the competitiveness of the export sector.

\section{Policy implications}

Commodity price booms require careful economic management to ensure that the resources generated by the improvement in the terms of trade are utilised efficiently and that the boom does not undermine macroeconomic stability and the competitiveness of the traded goods sectors. The analysis points to a range of policy implications which can be related to three general objectives: first, reducing the vulnerability of the domestic economy to trade shocks; second, enhancing the efficiency with which boom incomes are utilised; and third, ensuring that the fiscal and monetary stance maintains macroeconomic stability.

The structure of SSA economies implies that some degree of vulnerability to instability in international commodity markets is inevitable. This can be mitigated through commodity supply management policies (Bacon et al., 1996), export diversification (Kirkpatrick and Weiss, 1995) and broadening the government revenue base, for example by reducing dependence on trade taxes and emphasising revenue mobilisation from more widely based domestic consumption taxes such as value added taxes (Shalizi and Squire, 1988). 
A number of policy reforms are pertinent to ensuring that the transient income accruing from the boom is allocated efficiently. The real rates of return on both domestic and foreign financial assets should be attractive so as to prevent fixed investment being concentrated into the trade boom years. In economies characterised by financial repression, this would entail policies to liberalise domestic interest rates and to improve access to foreign-exchange-denominated assets (such as foreign-currency bank accounts). It should be noted that this combination of domestic financial market liberalisation and liberalisation of the capital account of the balance of payments has contributed to serious macroeconomic instability in a number of middle-income developing countries in Latin America (McKinnon, 1988; Villanueva and Mirakhor, 1990). This suggests that policy reform needs to be carefully sequenced, with domestic financial market liberalisation being consolidated before opening up the balance-of-payments capital account. In financially underdeveloped SSA the most feasible policy is likely to be an increase in nominal rates of interest to levels which ensure positive real rates of return to financial savings. The liberalisation of imports should also enhance the efficiency of resource allocation.

In terms of intersectoral factor mobility, the removal of sector-specific ceilings on bank lending, sectoral foreign-exchange allocations and the liberalising of industrial and investment licensing requirements should allow a more flexible movement of resources in response to changing patterns of demand and thus raise the price elasticity of the supply of non-traded capital goods, which may also be impeded by monopolistic control in the production and/or distribution of essential inputs such as cement. Measures to liberalise these markets are therefore likely to enhance supply elasticities.

In order to avoid a long-run increase in the fiscal deficit, the increase in public expenditure during the boom should be limited to any rise in permanent income accruing to the government, i.e. the sustainable increase in revenues which could be generated by investing windfall tax receipts. This would imply an increase in public sector saving and a fall in the government deficit during a temporary boom when current revenues exceed permanent income. This would help to dampen the rise in relative non-traded capital goods prices and therefore the reduction in rates of return arising from the private sector investment boom, and would also serve to limit the overall increase in aggregate demand and the rate of money-supply growth.

The importance of protecting and promoting foreign-exchange-earning industries in SSA countries would suggest that monetary and exchange-rate policy should be primarily directed towards minimising the appreciation of the real exchange rate. Under a fixed exchange-rate regime, a real appreciation requires domestic inflation (at rates higher than those of the country's trading partners) and an expansion of the money supply. To prevent this, monetary policy has to be used to sterilise the increase in the money supply brought about 
by balance-of-payments surpluses. Under a market-determined regime, the excess foreign exchange accrued during the boom will induce a nominal exchange-rate appreciation, which the Central Bank could prevent by means of a policy of accumulating foreign-exchange reserves. This would lead to increases in the monetary base as the counterpart to the purchases of foreign currency, however, and the maintenance of real exchange-rate stability is likely to require the sterilisation of these monetary injections in a similar manner to that entailed under a fixed-rate regime.

Table 1 summarises the various policies which should facilitate the appropriate management of a trade boom.

\section{Table 1}

Policy reforms applicable to the management of positive commodity price shocks

\section{Objectives}

Reducing vulnerability to trade shocks

Promoting efficient allocation of transient income

Maintenance of macroeconomic stability

\section{Policies}

Commodity supply management

Broadening government revenue base, e.g. introduction of VAT

Export diversification strategy

Raise deposit interest rates to positive real levels and/or liberalise interest rates

Import liberalisation sustainable with other components of policy stance

Removal of sectoral credit and foreign-exchange allocations

Liberalisation of industrial and investment licensing requirements

Removal of monopolies in the production and/or supply of non-traded capital goods inputs (e.g. cement).

Restraint on public investment during commodity price boom so as to avoid crowding out private investment

Tight control on government expenditures and borrowing. Public savings should rise during commodity price booms and fiscal policy should be countercyclical Sterilisation of monetary base increases arising from BoP surpluses

Prevention of real exchange-rate appreciation through restraint of aggregate demand growth and inflation 


\section{Structural adjustment and the management of trade booms}

Developments in world commodity markets during 1994 were the most favourable for many of the non-oil exporters of SSA since the late 1970s, with sharp rises in the prices of coffee, cocoa and copper. In the intervening period most SSA countries have undertaken World Bank-sponsored SAPs. ${ }^{6}$ This raises the key question of whether the reforms introduced by these programmes have left the region in a better position to manage the commodity price booms of the 1990s such that the transient income windfall can be converted into a permanent income gain. Their efficacy can be discussed from three standpoints: whether they have reduced the vulnerability of SSA countries to trade shocks through trade and government tax-base diversification; whether they will enable export boom income to be saved and invested in a more efficient manner; and whether they can ensure that the boom does not exacerbate macroeconomic instabilities.

Although the SAP reforms were primarily intended to address the problems of long-term domestic policy deficiencies (Toye, 1994; World Bank, 1981) and those caused by permanent changes in the external economic environment (Mosley et al., 1991, Vol. 1: 23), they are not necessarily incompatible with the measures required to enhance the management of commodity booms. In order to ascertain the degree of compatibility, the reforms implemented in a multi-country sample of SAPs in SSA (World Bank, 1994; Mosley et al., 1991; and Mosley, 1994) can be compared with the policy prescriptions summarised in Table 1.

\section{Structural adjustment and diversification}

In SSA export diversification is likely to consist of expanding the production of non-traditional commodities, processed or manufactured goods, and, for some countries, services such as tourism. Within the context of SAPs, the main policy mechanisms have been trade and exchange-rate reforms designed to increase incentives for exports of all kinds. These have been accompanied in several SSA countries by additional incentives aimed at non-traditional exports, including the provision of export earnings retention schemes, duty drawbacks, Export Processing Zones, and various fiscal incentives (World Bank, 1994: 75-6). The benefits of these policies appear to have been confined largely to the traditional primary commodities such as cocoa, coffee and sugar (Stewart, 1994: 107). As yet there is little evidence to indicate that much more than very limited

6. By 1992 a total of 38 SSA countries had implemented either an economy-wide SAP and/or sectoral adjustment programmes backed by financial support from the international financial institutions, with the World Bank providing $\$ 7.1$ billion. Structural adjustment has therefore become a dominant policy influence throughout the region. 
Table 2

Number of commodities exported and indices of export commodity concentration in SSA adjusters: 1980 and 1990

Country

Benin

Burkina Faso

Burundi

Cameroon

Central African Republic

Chad

Congo

Côte d'Ivoire

Gabon

The Gambia

Ghana

Guinea

Guinea-Biseau

Kenya

Madagascar

Malawi

Mali

Mauritania

Mozambique

Niger

Nigeria

Rwanda

Senegal

Sierra Leone

Tanzania

Togo

Uganda

Zambia

Zimbabwe
No. of commodities exported Commodity concentr. index 1980 1990 1980 1990

\section{0}

43

26

90

15

15

29

154

46

23

55

23

22

143

53

47

40

24

n.a.

39

147

13

113

39

83

51

22

49

87
29

23

7

103

25

17

34

106

45

22

54

28

n.a.

183

70

35

41

20

44

102

16

106

16

66

47

13

33

170
0.415

0.476

0.594

0.409

0.415

0.794

0.890

0.383

0.763

0.418

0.729

0.905

0.331

0.383

0.501

0.490

0.477

0.661

n.a.

0.821

0.948

0.668

0.271

0.444

0.286

0.468

0.950

0.717

0.257
0.482

0.481

0.744

0.311

0.588

0.688

0.797

0.345

0.812

0.353

0.450

0.840

n.a.

0.239

0.309

0.656

0.565

0.621

0.767

0.959

0.552

0.251

0.458

0.250

0.468

0.868

0.931

0.245

Notes: $\mathrm{n} . \mathrm{a} .=$ not available. The number of commodities exported refers to products at the three digit SITC level, the value of which was greater than $\$ 50,000$ in 1980 or $\$ 100,000$ in 1990 or was more than $0.3 \%$ of the country's total exports. The export concentration index is a Hirschmann index which takes values between 0 and 1 . Higher values of the index denote a greater commodity concentration of exports: i.e., a single commodity or a few commodities account for a larger proportion of total exports.

Source: UNCTAD, Handbook of International Trade and Development Statistics, 1992: $241-4$. 
progress has been achieved in boosting non-traditional exports (Kirkpatrick and Weiss, 1995).

Table 2 provides some statistical data on the extent to which the 29 SSA countries implementing SAPs during the period 1987-91 covered in the World Bank (1994) study diversified their exports in the 1980s. Of the 27 countries for which data were available, 16 exported a smaller number of commodities in 1990 than in 1980 . Although a majority were able to reduce commodity concentration, the extent of the reduction was very limited.

The emphasis placed by SAPs on price reforms to boost exports is likely to be of greater benefit to the traditional primary commodity exports than to non-traditional exports, since the latter often face other severe constraints, such as inadequate technological, managerial, technical and marketing skills and infrastructure, and lack of finance. Remedying these constraints has not been addressed in most SAPs in SSA. Hence the failure to achieve a significant degree of export diversification can be partly attributed to the policy composition of SAPs.

Progress has been achieved in only a few SSA countries in diversifying the government's revenue base away from an excessive concentration on trade taxes. This has primarily involved the introduction of consumption taxes (such as value added tax) in countries such as Cameroon, Tanzania, Malawi, Mauritius and The Gambia, although practical difficulties have usually meant that the tax base has not been extended much beyond imports and domestically produced manufactured items (Khalilzadeh-Shirazi and Shah, 1992). ${ }^{7}$

SSA countries can reduce their vulnerability to terms-of-trade shocks through commodity supply management policies (Bacon et al., 1996). Their SAPs have ignored the issue of supply management, however, leaving it instead to international commodity agreements, despite the latter's lack of success. Furthermore, because of the fallacy of composition whereby advising a large number of SSA countries simultaneously to increase their output of a given commodity can lead to excess supply and declining world prices, SAPs have made supply management harder (Godfrey, 1985; Akiyama and Larson, 1993).

Structural adjustment and efficiency of boom income savings and investment

Central to the issue of whether SAPs have removed obstacles to efficient investment of boom income is the argument that administrative controls over the prices and distribution of fixed and financial assets and/or uncompetitive market structures are likely to impede optimal resource allocation by the private sector,

7. The information in Mosley, 1994 (Appendix 6.1: 95-8) indicates that specific policy conditionality relating to tax reforms accompanied World Bank adjustment lending in only 5 out of 23 countries (Cameroon, Ghana, Malawi, Mauritius and Senegal). 
depressing savings rates and channelling income into investments with low rates of return. We focus our assessment on reforms in five important areas: interest rates; imports; sectoral credit controls; investment licensing; and controls in non-traded capital goods markets.

Financial markets have a crucial role to play in ensuring that rates of return to savings from boom income are maximised. Savers require attractive financial assets in which to hold their savings so that non-traded capital goods expenditures can be smoothed out beyond the end of the commodity boom. As bank deposits provide the main financial asset available to savers in most SSA countries, ensuring that bank deposits offer attractive rates of interest is essential. Interest-rate reforms have been an important feature of SAPs and real deposit rates have been increased in the majority of adjusting countries in SSA, for 21 of them from an average negative $4 \%$ during $1981-6$ to $1.6 \%$ in 1990-91, with 17 achieving an increase in the real deposit rate. Furthermore real deposit rates were positive in 15 of the 21 during 1990-91 compared with 12 in the earlier period.

The efficiency of resource allocation during a commodity boom will be reduced if desired investments are impeded because import controls prevent investors from purchasing imported capital goods. SAPs have involved a reduction of import restrictions in the majority of adjusting countries in SSA, in part reflecting the importance attached by the World Bank to trade policy reform. Quantitative restrictions such as non-tariff barriers (NTBs) were imposed on a wide range of imports in 21 out of 23 adjusting countries prior to the implementation of the reforms. By 1992 only 2 still retained comprehensive quantitative restrictions.

Controls on the allocation of foreign exchange have also been liberalised. Of 14 countries which controlled access to all foreign exchange before implementing SAPs, 6 had removed almost all restrictions by 1992, while an additional 6 countries had removed controls on the allocation of $50 \%$ or more of available foreign exchange.

Controls over the sectoral allocation of bank credit (the main source of finance for commercial enterprises in most SSA countries) may prevent savings from being channelled into the most productive investment projects. Formal administrative controls have usually taken the form of directives to banks to allocate a specified share of their loan portfolios to particular sectors or industries. Several SSA countries have implemented financial sector reform programmes which have included measures to liberalise credit controls and remove sectoral directives (Johnson, 1994). Ghana, for example, rescinded most sectoral directives in 1987 and had eliminated all by 1991. In Guinea and Madagascar, the banking system had been nationalised during the 1960 s or 1970 s with credit allocated mainly according to non-commercial criteria. Private capital and management have now been reintroduced, and this should ensure that commercial criteria play a more prominent role in credit allocation. 
The administrative regulation and licensing of investment and industry almost inevitably discourages investment or diverts it into less productive projects. Many of the adjusting countries have liberalised investment regulations since adopting SAPs, often as part of a package of incentives aimed at attracting a greater level of private sector investment.

Monopolies in non-traded capital goods markets are likely to impede efforts to invest boom income efficiently. Monopoly controls may prevent the optimal supply response to the increase in demand during a trade boom. Because of economies of scale and government intervention, the cement industry, the key input to the building industry, has been characterised by widespread market concentration in SSA. Monopoly controls over cement production and distribution have been reduced in only a few of the SSA countries undertaking SAPs. Of 19 adjusting countries, 15 had monopolies in markets for domestic cement production prior to the implementation of SAPs. By late 1992 the number with competitive cement markets had increased to only $7 ; 7$ countries retained public sector monopolies, while private sector monopolies prevailed in 5.

\section{Improving the macroeconomic management of trade booms}

The assessment as to whether SAPs have enhanced the capacity to manage the macroeconomy during a trade boom is based on two aspects of the implementation of the reforms. First, we examine whether macroeconomic performance in the non-boom periods has improved: reduced fiscal deficits, lower inflation and more realistic exchange rates could be taken as evidence that the capacity to manage the macroeconomy has improved and therefore that any subsequent commodity boom will also be better managed. Secondly, we examine whether a number of technical changes affecting macroeconomic policy instruments are likely to have enhanced the capacity for more appropriate macroeconomic management during a commodity boom: these include public expenditure and investment controls; monetary policy operating techniques; and methods of exchange-rate determination.

The World Bank (1994, Chapter 2 and Appendix B) claims that some improvements in macroeconomic policies have been attained, although none of the countries surveyed has what it regards as a 'good' overall macroeconomic stance. ${ }^{8}$ The fiscal position in SSA had been characterised by very large deficits in the first half of the $1980 \mathrm{~s}$. The adjusting countries attained on average only a small reduction from $6.4 \%$ of GDP during $1981-6$ to $5.2 \%$ during $1990-91$.

8. The overall macroeconomic stance was evaluated by combining data on the fiscal deficit, seigniorage, inflation and real interest rates, and the parallel market exchange-rate premium or change in the real effective exchange rate. 
Monetary policy was regarded by the World Bank as reasonably satisfactory, with inflation falling from a median of $10.6 \%$ in 1981-6 to 8\% in 1990-91. SSA countries required real exchange-rate devaluations in the 1980s for two reasons; rates had become overvalued due to high rates of domestic inflation combined with fixed nominal exchange rates, while the long-term downturn in the external terms of trade also required a depreciation of the exchange rate to restore external competitiveness. Progress has been made by the SSA countries in lowering real exchange rates and reducing parallel market exchange-rate premiums; 12 out of 15 non-CFA zone countries achieved a median real depreciation of $64 \%$ between 1980 and 1990-1 (World Bank, 1994: 45-57).

The World Bank study (1994: 124-6) indicates that, although efforts to improve budgetary procedures have been made in most adjusting countries, progress appears to have been limited. By 1992 only a minority of countries had established effective systems for monitoring and controlling payrolls and investment projects. Of 29 adjusting countries, only 6 were regarded as having systems which were free of significant problems, while 18 had failed to introduce systems for monitoring all public sector investment projects.

Monetary policy reforms enacted as part of SAPs in a number of SSA countries have involved measures to introduce market-based policy instruments in place of direct controls such as bank-specific lending ceilings and regulated interest rates. Essentially this required the Central Bank to intervene by purchasing foreign exchange (and therefore accumulating foreign reserves) and to sterilise the induced injections into the money supply using the available market-based monetary policy instruments. The main ones have been primary issues of government or Central Bank securities in combination with rediscount facilities: these have been referred to as 'open market type operations' (Johnston and Brekk, 1991: 97). Countries which have introduced monetary policy instruments of this type include Ghana, Kenya and Malawi. Part of the underlying rationale is that these market-based systems of monetary control offer the authorities potentially more effective and flexible instruments for controlling monetary aggregates (ibid., 1991: 98-9). However, their efficacy in the context of SSA economies is also potentially problematic. Because of the shallow nature of their financial markets (and in particular markets for securities), using open-market type operations to target a monetary aggregate might lead to excessive interest-rate volatility. It also imposes much greater demands on the Central Bank in terms of operational requirements for collating and using information, and forecasting (Roe, 1991: 18). Central Banks will therefore need time to develop the relevant expertise. As a consequence, the change in operating techniques may in the short term introduce considerable uncertainty into the financial markets, making effective monetary management more difficult.

Many SSA countries undertaking SAPs in recent years have begun to introduce market-determined exchange-rate systems. Countries which have 
introduced 'floating' exchange rates include Ghana, Sierra Leone, Zambia, Tanzania and Kenya. Reforms of this nature have generally entailed two major components: the liberalisation of access to foreign exchange and a system for trading foreign exchange, e.g. regular auctions and/or the development of interbank foreign-exchange markets (Mistry, 1994: 122). One of the concerns expressed about the adoption of floating exchange rates is that they may lead to excessive nominal exchange-rate volatility in response to large or unexpected shifts in the supply of, or demand for, foreign exchange. The optimal policy during a commodity boom is likely to involve intervention by the Central Bank, which in the context of a liberalised foreign-exchange market will necessitate purchasing foreign exchange from the market: ie the Central Bank will have to attempt a managed float. As with the move towards market-based systems of monetary control, this type of exchange-rate management is likely to impose substantial requirements in terms of operating expertise on Central Banks. In the short term they may lack the requisite experience and capacities to intervene effectively and as a consequence exchange-rate management in the face of shocks such as commodity booms may become more difficult.

\section{Conclusions}

The experience of the 1970s export commodity price booms in SSA indicated that many of the countries in the region had economic policy regimes which prevented them from deriving maximum benefits from temporary windfalls of foreign exchange. Instead, most of these countries found themselves facing severe macroeconomic imbalances once the boom had ended. Since the last major commodity boom in the 1970s, most SSA countries have undertaken comprehensive programmes of economic policy reform. Table 3 summarises the extent to which SAP reforms have improved SSA's capacity to manage commodity booms.

The SSA countries appear to have achieved very little export diversification since adopting SAPs, and as a consequence remain heavily reliant on a few primary commodities for the bulk of their export earnings. In part this reflects the policy composition of SAPs; exchange-rate and agricultural price and marketing reforms have mainly been of benefit to traditional exports, while insufficient emphasis has been placed on the specific policy measures needed to promote the development of non-traditional exports. In only a handful of countries have reforms included measures to diversify the government's revenue base, principally through the introduction of consumption taxes as an alternative to trade taxes. Because of the fallacy of composition, SAPs have made successful implementation of commodity supply management policies more difficult. 
Table 3

The extent to which SAP reforms have improved capacity to manage commodity price booms

Objective

SAP progress

1. Diversification

a. Export base

b. Tax base

c. Commodity supply management a. Minimal progress

b. Progress in only a handful of countries

c. Made harder

\section{Savings and investment efficiency}

a. Raising real deposit interest rate

a. Substantial progress

b. Removing NTBs

b. Substantial progress

c. De-control on foreign-exchange allocation

c. Substantial progress

d. Liberalising cement production

d. Minimal progress

e. De-controlling credit allocation

e. Progress in some countries

f. Liberalising investment licensing

f. Progress in some countries

\section{Macro-policy management}
a. General macro-policy stance
b. Controlling public expenditure
c. Monetary policy conduct
d. Exchange-rate management
a. Moderate improvement
b. Little progress
c. Made harder in the short term
d. Made harder in the short term

Mechanisms for efficiently mobilising and allocating savings and investment are crucial if the transient income accruing from a commodity boom is to produce maximum benefits in terms of enhancing permanent income gains. The construction boom analysis discussed in this article indicated that the extensive control regimes imposed on SSA economies (especially financial repression, and import and price controls) led to a sub-optimal use of boom income. Excessive levels of investment, concentrated in a short time period, in non-traded capital goods, pushed up the price of these goods and led to a decline in rates of return.

The liberalising strategy entailed in SAPs has significantly reduced the extent of the control regime in SSA countries. Real interest rates have been raised to positive levels in most adjusting countries, offering savers an alternative savings outlet to the purchase of fixed assets. Import restrictions have been liberalised, with substantial reductions in the extent to which imports are subject to 
non-tariff barriers. Controls on the sectoral allocation of bank credit have been removed in a number of countries and investment licensing procedures have been liberalised. Rather less progress has been made in eliminating monopolies in the production of inputs into non-traded capital goods, such as cement.

As a consequence, SAPs have almost certainly moved SSA economies towards a policy regime which is more conducive to saving and investing boom income efficiently. Nevertheless, a number of obstacles to the optimal allocation of savings and investment undoubtedly remain, not only in terms of administrative controls but also arising from market failures in other areas, in particular in the financial system. Adjusting countries in SSA have made moderate improvements in macroeconomic policy during the non-boom period since the mid-1980s, although this does not necessarily ensure that current and future commodity booms will be appropriately managed. Various technical reforms under way in adjusting countries, which are likely to enhance macroeconomic management capabilities, included measures to improve public expenditure control, monetary policy and exchange-rate determination. Although restraining the growth of public expenditures is crucial to maintaining macroeconomic stability during a trade boom, effective systems for controlling public employment and investment projects have not yet been put in place in the majority of SSA countries. Institutional reforms in the conduct of monetary policy and exchange-rate determination are intended to strengthen macroeconomic management in the long term, but in the short term may involve a period of greater uncertainty as the necessary experience and expertise are acquired by the authorities and by market participants.

The primary rationale for SAPs in SSA has been to address longer-term economic problems rather than those arising from cyclical factors such as commodity booms. Nevertheless, the policy reforms are likely to have brought about some benefits for SSA countries in terms of their ability to manage commodity price booms. The failure to diversify the export base, however, means that the need for an appropriate domestic policy regime and policy responses to commodity price booms remains as great now as it was during the 1970s. Clearly there is still scope for future SAPs to introduce reforms which would improve countries' ability to manage commodity price shocks.

\section{References}

ADE (1992) 'Trade Policy Reform in Sub-Saharan Africa: The Past Experience'. Report prepared for EDF, Louvain-La-Neuve, Belgium.

Akiyama, T. and Larson, D. (1993) Adding-up Problem-Strategies for Primary Commodity Exports in Sub-Saharan Africa. PPR Working Paper 1245. Washington, DC: World Bank International Economic Department.

Alpine, Robin W. and Pickett, James (1993) Agriculture, Liberalisation and Economic Growth in Ghana and Côte d'lvoire 1960-1990. Paris: OECD. 
Bacon, R., Maizels, A. and Mavrotos, G. (1996) Supply Management Policies for Primary Commodities. Oxford: Oxford University Press.

Bevan, David, Collier, Paul and Gunning, Jan Willem (1989) 'The Theory of Construction Booms: The New Macroeconomics of External Shocks'. Oxford: Centre for the Study of African Economies (mimeo).

Bevan, David, Collier, Paul and Gunning, Jan Willem (1990) Controlled Open Economies. Oxford: Clarendon Press.

Bevan, David, Collier, Paul and Gunning, Jan Willem (1992) 'The Oil Price Boom In Nigeria'. Oxford: Centre for the Study of African Economies (mimeo).

Corden, W.M., 1984, 'Booming Sector and Dutch Disease Economics: Survey and Consolidation', Oxford Economic Papers 36: 359-80.

Godfrey, Martin (1985) 'Trade and Exchange Rate Policy: A Further Contribution to the Debate' in Tore Rose (ed.) Crisis and Recovery in Sub-Saharan Africa. Paris: OECD.

Harrigan, Jane (1991) 'From Boom to Bust Trade: Malawi's Positive 1977-79 Trade Shock', paper prepared for World Bank Research Project No. 674-98. Oxford: Centre for the Study of African Economies (mimeo).

Johnson, Melanie (1994) 'Financial Sector Reform in Structural Adjustment Programmes' in Willem van der Geest (ed.) Negotiating Structural Adjustment in Africa. London and Portsmouth, NH: James Currey and Heinemann.

Johnston, R. Barry and Brekk, Odd der (1991) 'Monetary Control Procedures and Financial Reform: Approaches, Issues, and Recent Experiences in Developing Countries', in Philippe Callier (ed.) Financial Systems and Development in Africa. Washington, DC: World Bank, EDI Seminar Series.

Kaldor, Nicholas (1987) 'The Role of Commodity Prices in Economic Recovery', World Development 15(5): 551-8.

Khalilzadeh-Shirazi, Javed and Shah, Anwar (1991) Tax Policy in Developing Countries. Washington, DC: World Bank.

Kirkpatrick, C. and Weiss, J. (1994) 'Trade Diversification in African Least Developed Countries', paper prepared for UNCTAD project on Trade Diversification in Least Developed Countries. New York and Geneva: UNCTAD. Kirkpatrick, C. and Weiss, J. (1995) 'Trade Policy Reforms and Performance in Africa in the 1980s', Journal of Modern African Studies 33(2): 285-98.

Kraaij, Fred van der (1994) 'Background Notes on Sub-Saharan Africa', in Rolph van der Hoeven and Fred van der Kraaij (eds) Structural Adjustment and Beyond in Sub-Saharan Africa. London and Portsmouth, NH: James Currey and Heinemann.

Little, I.M.D, Cooper, Richard N., Corden, W. Max and Rajapatirana, Sarath (1993) Boom, Crisis and Adjustment. Oxford: Oxford University Press.

Maizels, Alfred (1987) 'Commodities in Crisis: An Overview of the Main Issues', World Development 15(5): 537-49.

Maizels, Alfred (1992) Commodities in Crisis. Oxford: Oxford University Press.

McKinnon, Ronald I. (1988) 'Financial Liberalisation in Retrospect: Interest Rate Policies in LDCs' in Gustav Ranis and T. Paul Shultz (eds) The State of Development Economics: Progress and Perspectives. New York: Basil Blackwell. 
Mistry, Percy (1994) 'Exchange Rate Adjustment: A Review of Developing Country Experience', in Willem van der Geest (ed.) Negotiating Structural Adjustment in Africa. London and Portsmouth, NH: James Currey and Heinemann.

Mosley, Paul (1994) 'Decomposing the Effects of Structural Adjustment: The Case of Sub-Saharan Africa', in Rolph van der Hoeven and Fred van der Kraaij (eds) Structural Adjustment and Beyond in Sub-Saharan Africa. London and Portsmouth, NH: James Currey and Heinemann.

Mosley, Paul, Harrigan, Jane and Toye, John (1991) Aid and Power: The World Bank and Policy-Based Lending, Volumes 1 and 2. London: Routledge.

Nashashibi, Karim and Bazzoni, Stefania (1993) 'Exchange Rate Strategies and Fiscal Performance in Sub-Saharan Africa', IMF Staff Papers 41(1). Washington, DC: IMF.

Neary, J. Peter (1984) 'Real and Monetary Aspects of the Dutch Disease', in K. Jungenfeld (ed.) Structural Adjustment in Developed Open Economies. London: Macmillan.

Roe, Alan (1991) 'Financial Systems and Development in Africa' in Philippe Callier (ed.) Financial Systems and Development in Africa. Washington, DC: World Bank, EDI Seminar Series.

Shalizi, Zmarak and Squire, Lyn (1988) Tax Policy in Sub-Saharan Africa. Washington, DC: World Bank.

Stewart, Frances (1994) 'Are Adjustment Policies in Africa Consistent with Long Run Needs', in Willem van der Geest (ed.) Negotiating Structural Adjustment in Africa. London and Portsmouth, NH: James Currey and Heinemann.

Toye, John, 1994, 'Structural Adjustment: Context, Origins and Diversity' in Rolph van der Hoeven and Fred van der Kraaij (eds) Structural Adjustment and Beyond in Sub-Saharan Africa. London and Portsmouth, NH: James Currey and Heinemann.

UNCTAD (1993a) Trade and Development Report, 1993. New York: United Nations.

UNCTAD (1993b) Handbook of International Trade and Development Statistics 1993. New York: United Nations.

UNCTAD (1993c) The Least Developed Countries 1992 Report. New York: United Nations.

Villanueva, Delano and Mirakhor, Abbas (1990) 'Strategies for Financial Reforms', IMF Staff Papers 37(3). Washington, DC: IMF.

Wetzel, Deborah L. (1992) 'Temporary Trade Shocks in Developing Countries: A Case Study of the Ghanaian Cocoa Boom'. Oxford: Centre for the Study of African Economies (mimeo).

Van Wijnbergen, Sweder (1984) 'Inflation, Employment, and the Dutch Disease in Oil-Exporting Countries: A Short-run Disequilibrium Analysis', Quarterly Journal of Economics: 233 -50.

World Bank (1981) Accelerated Development in Sub-Saharan Africa. Washington, DC: World Bank.

World Bank (1994) Adjustment in Africa. Washington, DC: World Bank. 


\section{How European Aid Works}

\section{A comparison of management systems and effectiveness}

\section{Aidan Cox, John Healey, and Antonique Koning}

In collaboration with Paul Hoebink, David Naudet, Gorm

Rye Olsen, Lars Udsholt, and Jürgen Wiemann

Authors from the aid programmes of six European research institutes critically assess five EU donor agencies - Denmark, France, Germany, the Netherlands, the UK - and the European Commission (DG VIII). The agencies are compared in terms of their political structures, objectives, organisation, management and procedures.

Answers are sought to a range of questions:

- Do the agencies prioritise their objectives and have effective mechanisms to transmit them into practice?

- Do they have a common approach to country strategies and programming?

- Do they have adequate staff with the right skills in the right place?

- How effectively do they manage projects?

- Do they learn the lessons of experience?

- What are the options for better co-ordination or a division of labour between European aid agencies?

By comparing donor organisations and experience in aid management, this book draws conclusions for improving aid effectiveness and seeks to contribute to the debate on coordination and complementarity of EU donors.

1996 240pp ISBN 0850032431 paper

Available from ODI Publications, Portland House, Stag Place, London SW1E 5DP

Tel: +44 (0)171 3931600

Fax: +44(0)1713931699

Email: publications@odi.org.uk 